\title{
Convergence of Innate and Adaptive Immunity during Human Aging
}

\author{
Branca I. Pereira and Arne N. Akbar* \\ Division of Infection and Immunity, University College London, London, UK
}

Aging is associated with profound changes in the human immune system, a phenomenon referred to as immunosenescence. This complex immune remodeling affects the adaptive immune system and the CD8 ${ }^{+} \mathrm{T}$ cell compartment in particular, leading to the accumulation of terminally differentiated $T$ cells, which can rapidly exert their effector functions at the expenses of a limited proliferative potential. In this review, we will discuss evidence suggesting that senescent $\alpha \beta C D 8^{+} T$ cells acquire the hallmarks of innate-like T cells and use recently acquired NK cell receptors as an alternative mechanism to mediate rapid effector functions. These cells concomitantly lose expression of co-stimulatory receptors and exhibit decreased $T$ cell receptor signaling, suggesting a functional shift away from antigen-specific activation. The convergence of innate and adaptive features in senescent $T$ cells challenges the classic division between innate and adaptive immune systems. Innate-like T cells are

OPEN ACCESS

Edited by:

Fernando A. Arosa,

University of Beira Interior, Portugal

Reviewed by:

Nan-ping Weng,

National Institute on Aging, USA

Rafael Solana,

University of Córdoba, Spain

${ }^{*}$ Correspondence:

Arne N. Akbar

a.akbar@ucl.ac.uk

Specialty section:

This article was submitted

to T Cell Biology,

a section of the journal

Frontiers in Immunology

Received: 09 September 2016

Accepted: 07 October 2016

Published: 04 November 2016

Citation:

Pereira Bl and Akbar AN (2016)

Convergence of Innate and Adaptive Immunity during Human Aging.

Front. Immunol. 7:445.

doi: 10.3389/fimmu.2016.00445 particularly important for stress and tumor surveillance, and we propose a new role for these cells in aging, where the acquisition of innate-like functions may represent a beneficial adaptation to an increased burden of malignancy with age, although it may also pose a higher risk of autoimmune disorders.

Keywords: aging, immunosenescence, natural killer receptors, T cell receptor, innate-like T lymphocytes

\section{INTRODUCTION}

Natural killer cells and $\alpha \beta C D 8^{+} \mathrm{T}$ lymphocytes are the two major cell lineages with constitutive cytotoxic activity and have a crucial role in the recognition and killing of abnormal cells. However, the paradigm for the recognition of target cells is fundamentally different between these two cell types: conventional $\alpha \beta C D 8^{+} \mathrm{T}$ cells rely on the $\mathrm{T}$ cell receptor (TCR) to recognize specific peptides presented by major histocompatibility complex class-I (MHC-I) molecules, whereas NK cells use a repertoire of germ line-encoded receptors to detect "missing self" or "altered-self" antigens and directly kill abnormal cells, without prior sensitization (1). Besides antigen specificity, the development of immunological memory is conventionally another distinctive feature between NK and $\mathrm{T}$ cells, categorizing them into distinct arms of the immune system and the innate and adaptive immune system, respectively (2).

Nevertheless, accumulating evidence supports the existence of NK cell memory $(3,4)$, as well as evidence for TCR-independent responses mediated by $\alpha \beta C D 8^{+} \mathrm{T}$ lymphocytes $(5-7)$, suggesting that the conventional limits between the innate and adaptive arms of the immune system may be not as distinct as first thought (8). NK and T lymphocytes have a common origin from a lymphoid progenitor cell in the bone marrow (9), and recent comparative proteomic and transcriptomic studies have demonstrated a remarkably close proximity between effector 
$\alpha \beta \mathrm{CD}^{+} \mathrm{T}$ lymphocytes and NK cells $(10,11)$, reiterating an evolutionary ancestry and shared biology between the two cell lineages.

An increasing body of literature reveals the existence of subsets of $\mathrm{T}$ cells with features that bridge innate and adaptive immunity (12-14). In humans, these innate-like T cells comprise the invariant natural killer T (iNKT) cells, CD1d-restricted natural killer $\mathrm{T}$ (NKT) cells, mucosa-associated invariant T (MAIT) cells, and $\gamma \delta \mathrm{T}$ cells. These cells typically co-express a TCR and NK cell lineage markers, distinguishing them from NK cells and other innate lymphoid cells (ILCs), which lack the expression of a TCR or somatically rearranged receptors. Functionally, innate-like T cells respond to TCR ligation but are also able to respond rapidly to danger signals and pro-inflammatory cytokines, independently of TCR stimulation, resembling innate cells. Recently, subsets of conventional $\alpha \beta C D 8^{+} \mathrm{T}$ cells expressing NK cell markers and intraepithelial $\mathrm{T}$ cells have been included in this vaguely defined group of innate-like $\mathrm{T}$ cells $(15,16)$. Despite the similarities in phenotype and function, there are clear differences in ontogeny and tissue distribution between them.

In this review, we will discuss recent evidence that aging is associated with the expansion of a subset of conventional $\alpha \beta C D 8^{+}$ $\mathrm{T}$ cells with phenotypic, functional, and transcriptomic features that resemble NK cells. Such innate-like $\alpha \beta C D 8^{+} \mathrm{T}$ cells have the characteristics of terminally differentiated $\mathrm{T}$ cells, and the acquisition of functional NK receptors is most likely part of a general reprograming of the $\mathrm{CD}^{+} \mathrm{T}$ cell compartment during human aging, to ensure broad and rapid effector functions. We propose that innate-like $\alpha \beta C D 8^{+} \mathrm{T}$ cells share important features with other innate-like $\mathrm{T}$ cells; however, fundamental differences in origin and development separate them from truly innate cells. Interestingly, these cells are also differentially affected by aging, suggesting distinct roles in immune responses at different times of life.

\section{IMMUNOSENESCENCE}

Aging is associated with a general decline in immune function, contributing to a higher risk of infection, cancer, and autoimmune diseases in the elderly. Such faulty immune responses are the result of a profound remodeling of the immune system that occurs with age, generally termed as immunosenescence (17). While the number of naive $\mathrm{T}$ cells emerging from the thymus progressively decreases with age as a result of thymic involution (18), the memory $\mathrm{T}$ cell pool expands and exhibits significant changes in the phenotype and function of antigen-experienced $\mathrm{T}$ cells, particularly evident in the CD8 ${ }^{+} \mathrm{T}$ cell compartment (19). Chronic immune activation due to persistent viral infections, such as cytomegalovirus (CMV) and Epstein-Barr virus (EBV), is one of the main drivers contributing to the accumulation of highly differentiated antigen-specific $\mathrm{CD}^{+} \mathrm{T}$ lymphocytes that have characteristics of replicative senescence $(20,21)$. In combination with the depletion of the peripheral pool of naïve $T$ cells, the accumulation of these terminally differentiated $\mathrm{T}$ cells with age skews the immune repertoire and has been implicated in the impaired immune responses to new antigens and vaccination in the elderly $(22,23)$.
The widespread effects of aging on the immune system have been reviewed elsewhere (24) and include defects in the function of natural killer cells, neutrophils, macrophages, and dendritic cells as well as B cells and hematopoietic stem cells. In the innate immune compartment, changes in the phenotype and function of NK cells have been described (25) and associated with the accumulation of CD56 $6^{\mathrm{dim}} \mathrm{NK}$ cells with a mature phenotype, characterized by the increased expression of maturation markers, such as CD57 (26) and KLRG1 $(27,28)$. Although the effects of aging on the cytolytic function of NK cells are still controversial, our group recently identified a subset of CD56 dim KLRG $1^{\text {high }}$ NK cells that is expanded in the elderly, displaying impaired cytotoxicity and proliferation as well as other features of senescence (28).

While many aspects of the immune response are impaired, there is also evidence for hyperresponsiveness of the immune system during aging (29). It is likely that there is a complex remodeling of the immune system throughout life in an attempt to maintain effective immune responses, which could be beneficial in the responses to infections and cancer but may carry an increased risk of autoimmune and inflammatory diseases in the elderly (30).

\section{CHARACTERISTICS OF HIGHLY DIFFERENTIATED $\alpha \beta C D 8^{+}$T CELLS}

Multiple phenotypic and functional features have been proposed to define senescent $\mathrm{CD}^{+} \mathrm{T}$ cells (Table $\mathbf{1}$ ). Loss of co-stimulatory receptors, such as $\mathrm{CD} 28$ and $\mathrm{CD} 27$, is one of the most consistent immunological markers of $\mathrm{T}$ cell aging $(31,32)$ which, in combination with other markers of maturation such as CD45RA, KLRG1, and CD57 expression, identifies a subpopulation of long-lived immune cells with characteristics of terminal differentiation or senescence (33).

Several lines of evidence indicate that end-stage $\mathrm{CD}_{2} 7^{-}$ CD28-CD45RA ${ }^{+} \mathrm{CD}^{-} 7^{+} \mathrm{T}$ cells accumulate significantly in older humans (34), during chronic viral infections (35) and in chronic inflammatory diseases (36). These cells exhibit the characteristic features of senescence that include accumulation of DNA damage markers, short telomeres, low proliferation, and loss in the capacity to activate the enzyme telomerase (37-39). A paradoxical observation is that senescent $\mathrm{CD}^{+}$ $\mathrm{T}$ cells maintain potent effector functions, despite the loss of proliferative capacity, and thus should not be considered as a residual population of dysfunctional cells. On the contrary, these cells are polyfunctional, reflecting their ability to simultaneously carry out multiple functions, including secretion of IFN- $\gamma$ and TNF- $\alpha$ and cytotoxicity $(35,38,40)$, and this is an important observation that distinguishes senescent from exhausted $\mathrm{T}$ cells (41). Nevertheless, the increased secretion of pro-inflammatory cytokines by senescent $\mathrm{T}$ cells may have detrimental effects on the tissue microenvironment and contribute to the age-associated low-grade inflammatory state termed "inflammaging" (42).

Highly differentiated $\mathrm{T}$ cells have impaired TCR signaling $(43,44)$. We recently described that senescent CD27-28- CD4 ${ }^{+}$ $\mathrm{T}$ cells exhibit decreased expression of key components of the TCR signalosome, such as LCK, LAT, and SLP-76 (39), and found 
TABLE 1 | Phenotypic and functional characteristics of senescent CD8 ${ }^{+}$ $T$ cells, compared to less differentiated subsets.

\begin{tabular}{|c|c|c|c|}
\hline & $\begin{array}{c}\text { Early } \\
\text { differentiation }\end{array}$ & $\begin{array}{l}\text { Intermediate } \\
\text { differentiation }\end{array}$ & $\begin{array}{c}\text { Terminal } \\
\text { differentiation }\end{array}$ \\
\hline \multicolumn{4}{|c|}{ Phenotypic markers } \\
\hline CD28 & ++ & $+/-$ & - \\
\hline CD27 & ++ & $+/-$ & - \\
\hline CD45RA & ++ & $+/-$ & $+/-$ \\
\hline CCR7 & ++ & + & - \\
\hline CD62L & ++ & + & - \\
\hline CD57 & - & $+/-$ & ++ \\
\hline KLRG1 & - & $+/-$ & ++ \\
\hline $\begin{array}{l}\text { Other NKR (KIR, } \\
\text { NKG2, and CD56) }\end{array}$ & - & $+/-$ & ++ \\
\hline \multicolumn{4}{|c|}{ Functional features } \\
\hline Proliferation & ++ & + & - \\
\hline $\begin{array}{l}\text { Telomerase } \\
\text { activity }\end{array}$ & ++ & + & - \\
\hline Telomeres & +++ & ++ & + \\
\hline Cytotoxicity & - & + & ++ \\
\hline $\begin{array}{l}\text { Cytokine secretion } \\
\text { (TNF- } \alpha \text {, IFN- } \gamma \text { ) }\end{array}$ & - & + & ++ \\
\hline \multicolumn{4}{|c|}{ Signaling pathways } \\
\hline TCR signaling & + & ++ & $+/-$ \\
\hline IL-2 signaling & + & ++ & $+/-$ \\
\hline $\begin{array}{l}\text { Pi3K-AKT-mTOR } \\
\text { signaling }\end{array}$ & + & ++ & $+/-$ \\
\hline $\begin{array}{l}\text { p38MAPK } \\
\text { activation }\end{array}$ & - & - & + \\
\hline
\end{tabular}

KLRG1, killer cell lectin-like receptor G1; NKR, natural killer receptor; KIR, killer cell immunoglobulin-like receptor; NKG2, natural killer receptor G2, TNF- $\alpha$, tumor necrosis factor alpha; IFN- $\gamma$, interferon gamma; PI3K, phosphatidylinositol-3 kinase; mTOR, mammalian target of rapamycin.

similar observations in end-stage $\mathrm{CD}^{+} \mathrm{T}$ cells. Interestingly, as $\mathrm{T}$ cells progressively differentiate, they concomitantly start expressing NK lineage receptors. Collectively, these observations suggest that, as $\mathrm{CD}^{+} \mathrm{T}$ cells terminally differentiate, they become less dependent on antigen-specific signals and more responsive to innate-like signals.

\section{TCR HYPORESPONSIVENESS IN TERMINALLY DIFFERENTIATED T CELLS}

Conventionally, optimal activation of $\mathrm{T}$ cells requires the engagement of the TCR and the second signal usually delivered by co-stimulatory receptors or cytokines. However, as previously mentioned, $\mathrm{T}$ cell senescence is associated not only with the loss of co-stimulatory receptors but also with impairment of TCR signaling $(43,44)$, leading to defects in classical T cell functions.

Changes in the composition of membrane lipids and lipid rafts have been described and linked to the age-related changes in TCR proximal signaling (45). More recently, Li and colleagues investigated the molecular mechanisms accounting for the loss of TCR sensitivity with age and found a correlation with the decreased expression of miR-181a and increased activity of DUSP6, a phosphatase that negatively regulates proximal TCR signaling (46). We recently demonstrated that the accumulation of DNA damage in senescent $\mathrm{CD}^{+} \mathrm{T}$ cells leads to the activation of AMP kinase, which is implicated in the decreased expression of key elements of the proximal TCR machinery, leading to impaired proximal TCR signaling in these cells (39). It is evident from these studies that aging is associated with a decrease in TCR responsiveness. Interestingly, recent studies have linked the acquisition of innatelike effector functions by memory CD8 T cells with defective TCR signaling (47-49).

\section{TCR-INDEPENDENT ACTIVATION OF $\alpha \beta C D 8^{+} T$ CELLS}

Accumulating evidence indicates that memory $\mathrm{CD}^{+} \mathrm{T}$ cells may be activated in a TCR-independent manner through a process called bystander activation. This occurs in the absence of the cognate antigen, through the action of inflammatory cytokines, such as type I interferons (50, 51), IL-15 (52), IL-12 (53), IL-18, or a combination of these $(5,7,54)$.

In addition to inflammatory cytokines, the acquisition of stimulatory innate immune receptors has been implicated in antigen-independent activation of $\mathrm{CD} 8^{+} \mathrm{T}$ cells. Among them, C-type lectin activating receptors, such as NKG2D and NKG2C, which recognize self-ligands related to the MHC-I have been shown to play crucial role in the mediation of innate-like responses by $\mathrm{CD}^{+} \mathrm{T}$ cells $(6,55)$. NKG2D is a classical example of a NK cell receptor that is highly expressed on $\alpha \beta C D 8^{+} \mathrm{T}$ cells and subsets of $\gamma \delta$ T cells $(56,57)$. While the general consensus is that NKG2D engagement serves as a costimulatory receptor in $\mathrm{CD} 8^{+} \mathrm{T}$ cells, amplifying TCR signals in virus-specific responses (58) as well as antitumor immunity $(59,60)$, other studies have provided compelling evidence that $\mathrm{CD}^{+} \mathrm{T}$ cells may respond to NKG2D ligation alone, without TCR engagement, provided that cells are stimulated with cytokines, such as IL-15 or high doses of IL-2 $(6,49,61,62)$. Such TCR-independent, NKG2D-dependent mechanism of activation of $\mathrm{CD}^{+} \mathrm{T}$ cells has been shown important for host defense against infections (49) and tumor surveillance (63) but has also been implicated in the pathogenesis of inflammatory and autoimmune reactions (6).

Collectively, these findings challenge the classic paradigm that TCR engagement by the cognate antigen is necessary for the activation of T cells and support the role of innate-like receptors in the regulation of $\mathrm{T}$ cell effector functions. Overall, such observations may shed light on the question of how senescent $\mathrm{T}$ cells maintain potent effector functions, despite the TCR hyporesponsiveness.

\section{EXPANSION OF $\alpha \beta C D 8^{+} T$ CELLS EXPRESSING NK CELL RECEPTORS WITH AGING}

Studies in human centenarians have shown an increased proportion of T cells expressing NK cell receptors (NKRs), whereas these cells represent a minor population of circulating lymphocytes in newborns and young healthy individuals $(64,65)$. The frequency of NKR-expressing T cells not only increases with age but also in conditions associated with chronic immune activation (66-68). Among the most commonly observed NKR on T cells are activating and inhibitory receptors, such as CD16, CD56, 
CD57, NKp30, KLRG1, and CD94, members of the NK receptor G2 (NKG2), and killer-cell immunoglobulin-like receptor (KIR) families (10, 66-69).

Phenotypic analysis of NKR-expressing $\mathrm{T}$ cells revealed that the majority of these cells are highly differentiated effector memory CD ${ }^{+} \mathrm{T}$ cells, lacking CD28 expression and exhibiting other features of senescence $(62,69-71)$. Importantly, it has been demonstrated that these cells derive from conventional $\alpha \beta C D 8^{+}$ T cells (71), express an oligoclonal $\alpha \beta T C R$, and do not express the semi-invariant TCR V $\alpha 24 / \mathrm{V} \beta 11$ chains, excluding that they represent an expansion of the classical iNKT cells (17).

A recent study using single-cell mass cytometry to analyze the expression of NKR across the human immune system found, as expected, an increased expression of NK cell markers on $\mathrm{CD}^{+} \mathrm{T}$ cells, more evident in individuals with high levels of CD57, indicative of a terminally differentiated immune system (10). As the immune system matures, the diversity of the NKR repertoire increases on both $\mathrm{NK}$ and $\mathrm{CD}^{+} \mathrm{T}$ cells; however, the difference in magnitude for the gain of activating receptors appears to be much higher in $\mathrm{CD} 8^{+} \mathrm{T}$ than in $\mathrm{NK}$ cells. Hierarchical clustering based on NKR expression patterns unexpectedly clustered $\mathrm{CD}^{+} \mathrm{T}$ cells closer to mature NK cells than to $\mathrm{CD} 4^{+} \mathrm{T}$ cells.

Although the expansion of NKR-expressing T cells is mostly evident in the $\mathrm{CD}^{+} \mathrm{T}$ cell compartment, the expression of NK cell markers has also been found on human $\mathrm{CD} 4^{+} \mathrm{T}$ cells. For instance, our group and others have identified a subset of highly differentiated $\mathrm{CD}^{+} \mathrm{T}$ cells expressing NKG2D as well as cytotoxic granules, expanded in aging $(35,72)$ and autoimmune diseases $(73,74)$.

What triggers the expression of NKRs on T cells with aging is not yet clearly defined. TCR engagement and cytokine stimulation have been shown to induce the expression of NKRs on $\mathrm{T}$ cells both in vitro and in vivo $(75,76)$. In addition, studies in transplant recipients have demonstrated a striking upregulation of NKR in virus-specific $\mathrm{CD}^{+} \mathrm{T}$ cells after $\mathrm{CMV}$ reactivation (77), suggesting that chronic antigenic stimulation may drive the expansion of NKR-expressing T cells. Likewise, the upregulation of inhibitory NKRs, such as NKG2A and KLRG1, has been linked to clonal expansion after antigenic exposure and development of replicative senescence of T cells $(20,34,78,79)$.

\section{REPROGRAMING OF SENESCENT $\alpha \beta C D 8^{+} T$ CELLS INTO INNATE-LIKE T CELLS}

The biological significance of NKR acquisition on $\mathrm{CD}^{+} \mathrm{T}$ cells during aging is not yet fully understood. It remains unclear whether the expansion of NKR-expressing $\mathrm{T}$ cells with age is a stochastic effect associated with chronic antigenic stimulation or whether it represents a predetermined program to allow these cells to respond rapidly in an innate-like fashion.

Functional studies performed with human $\mathrm{CD}^{+} \mathrm{T}$ cells that were activated and expanded ex vivo in the presence of cytokines or after TCR cross-linking, revealed that the acquisition of an NK cell phenotype was generally associated with the acquisition of functional features characteristic of NK cells (75). Of particular note, these cytokine-induced killer (CIK) cells develop the capacity to mediate MHC-unrestricted killing of target cells, in particular tumor cells, identifying them as potential tools in cancer therapy (80). Such activity does not require prior antigenic exposure but involves the engagement of stimulatory NKR and prior stimulation with inflammatory cytokines. Interestingly, these cells display a duality of function, as they are able to mediate both TCR-independent and antigen-specific immune responses (81).

Gene-expression studies have greatly contributed to dissecting the transcriptional changes occurring in aged $\mathrm{T}$ cells and shed light on the significance of NKR acquisition [reviewed in Ref. (82)]. Fann and colleagues originally compared the geneexpression profiles of human $\mathrm{CD} 28^{\text {null }}$ and $\mathrm{CD} 28^{+}$memory $\mathrm{CD} 8^{+}$ $\mathrm{T}$ cells and found significant changes in the CD28 $8^{\text {null }}$ compartment, such as (1) decreased expression of co-stimulatory receptors, (2) acquired expression of NKRs (the majority of which have stimulatory activity), (3) upregulation of genes involved in cytotoxicity (in particular genes involved in the granule exocytosis pathway, perforin and granzymes, and in the Fas ligand/Fas pathway), (4) elevated expression of chemokines and cytokine receptors, and (5) differentially expressed signaling molecules and transcription factors (83). Subsequent studies comparing gene-expression profiles of $\mathrm{CD} 8^{+} \mathrm{T}$ cells between young and old donors have found similar changes, particularly in relation to enhanced expression of genes in the NK cell cluster $(84,85)$. Of particular note, Cao et al. described additional changes at the level of cell signaling pathways in aged $\mathrm{CD}^{+} \mathrm{T}$ cells, the most prominent involving an age-decreased expression of genes associated with TCR, IGF-1, and PI3K/AKT signaling pathways (85). Collectively, these studies point to a common transcriptional signature in aged $\mathrm{CD} 8^{+} \mathrm{T}$ cells that most likely reflect the acquisition of potent cytotoxic effector functions, largely independent of TCR signals.

It remains to be determined which transcriptional factors are the main regulators of this program. The differential expression of T-box transcription factors, T-bet and eomesodermin (Eomes) in aged T cells compared to the less differentiated counterparts (83), suggests a role in the reprograming of senescent $\mathrm{CD}^{+} \mathrm{T}$ cells. However, several other transcriptional regulators have been implicated in the terminal differentiation of cytotoxic $\mathrm{CD}^{+} \mathrm{T}$ cells, including the Foxo family of transcription factors [reviewed in Ref. (86), Blimp-1 (87, 88), ZEB2 (89), and promyelocytic leukemia zinc finger (PLZF) (90)]. Interestingly, some of these factors have been also implicated in the transcriptional control of NK and NKT cell differentiation (91, 92), and PLZF has been proposed as the key determinant factor for the development of innate $\mathrm{T}$ cells $(92,93)$. More importantly, overexpression of PLZF in conventional T cells was sufficient for the acquisition of innate-like phenotype and functions (90). Many questions remain in regard to the transcriptional program underlying $\mathrm{T}$ cell senescence. Importantly, it remains to be determined which factors control the peripheral modulation of TCR signaling and whether there is a mechanistic link between the acquisition of NKRs and the modulation of the TCR machinery. 
Collectively, these observations indicate that the acquisition of receptors that are normally found on NK cells may be part of a general reprograming of $\mathrm{CD} 8^{+} \mathrm{T}$ cells with maturation (Figure $\mathbf{1}$ ). Not only these cells acquire phenotypic markers of NK cells but also they acquire innate-like cytolytic functions, suggesting that a coordinated transcriptional program endows these cells with the machinery to respond to innate stimuli, without the requirement for TCR activation.

\section{SIMILARITIES AND DIFFERENCES WITH INNATE-LIKE T CELLS}

Innate-like $\mathrm{T}$ cells are phenotypically characterized by the coexpression of a TCR with conventional NK cell lineage markers. NKT cells are the prototypical example of innate T lymphocytes. The term NKT cell is sometimes misused to refer to other subsets of conventional $\alpha \beta T$ cells that express NKRs, although there are fundamental differences between them. Classical NKT cells express an invariant TCR (Va24Ja18) that recognize glycolipids presented by the monomorphic CD1d molecule, and they account for $0.1-1 \%$ of $\mathrm{T}$ cells in human peripheral blood (94), whereas conventional $\alpha \beta$ T cells expressing NKR exhibit a diverse TCR repertoire and their frequency in peripheral blood is much higher, increasing with age and chronic inflammatory diseases (68). In striking contrast, aging is associated with decreased frequency and function of iNKT cells $(95,96)$.

Recently, it has been proposed that the suppression of TCR signaling is critical for the development of innate-like $\mathrm{T}$ cells. An elegant study done by Hayday and colleagues in mice models has brought some insights into how innate T cells downmodulate the TCR signaling machinery to allow an innate mode of activation in peripheral tissues, independent of the TCR (97). The authors demonstrated that this mechanism of TCR tuning after development in the thymus, concomitant with acquisition of responsiveness to innate signals is a feature shared by diverse subsets of innate-like T cells, including CD27- $\gamma \delta \mathrm{T}$ cells, mouse dendritic epidermal T cells (DETCs), and intestinal epidermal TCR $\alpha \beta^{+}$and $\gamma \delta^{+}$T cells. Although they could not find a similar mechanism to occur in iNKT cells, another study has

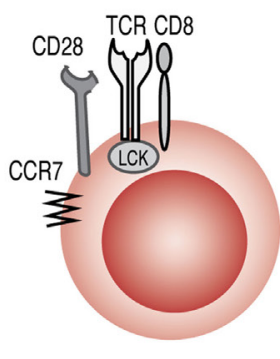

Early differentation

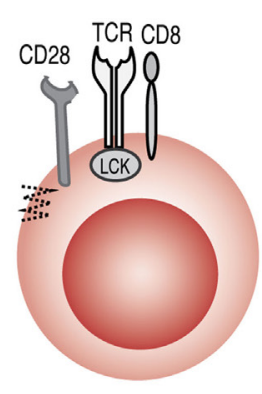

Intermediate differentation

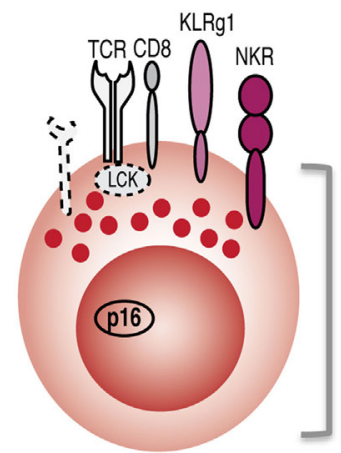

Oligoclona

CD28null

NKR expression

Short telomeres

Low proliferation

TCR hyporesponsive

Polyfunctional

Gain-of-function

(TCR-independent)

Terminal differentation or senescence

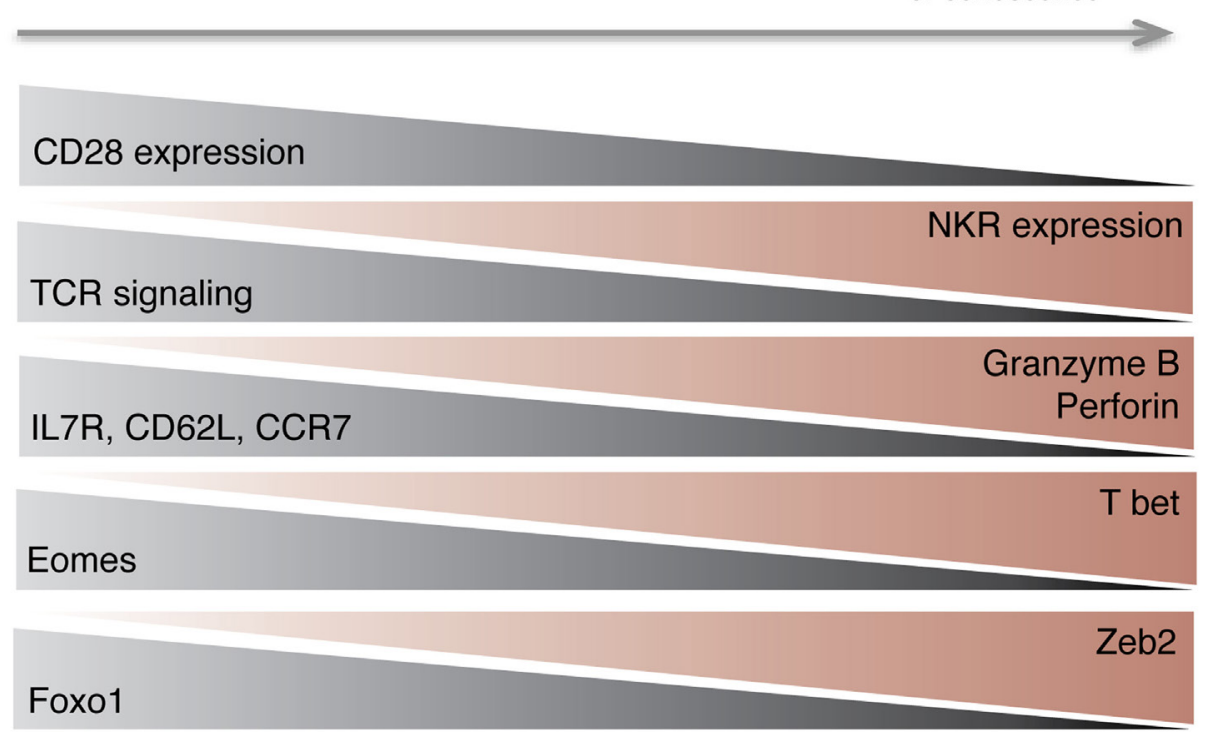

FIGURE 1 | Reprograming of CD8+ $\mathbf{T}$ cells into NK-like T cells with aging. Progression toward terminal differentiation or senescence is associated with phenotypic, functional, and transcriptional changes that lead to the expansion of NK-like CD8+ T cells. 
demonstrated the acquisition of transient innate responsiveness by human iNKT cells via histone modifications induced by weak TCR stimulation (98).

Functionally, it has been demonstrated that innate-like lymphocytes are able to respond to TCR ligation as well as to innate signals alone, in particular to NKG2D ligation and to inflammatory cytokines (99-101). In humans, conventional $\alpha \beta C D 8^{+}$cells in celiac disease have been shown to respond to NKG2D ligands and pathological levels of IL-15, independently of TCR ligation (6). It remains to be determined if TCR signaling is suppressed in these cells, suggesting a common signature with other innate-like T cells.

Collectively, the observations that terminally differentiated $\mathrm{CD}^{+} \mathrm{T}$ cells co-express NKR and TCR have decreased TCR responsiveness and yet are able to respond rapidly to stimulation, without the requirement for cognate antigen supports the hypothesis that human senescent $\alpha \beta C D 8^{+} \mathrm{T}$ cells exhibit phenotypic and functional features that resemble other innatelike T cells. Nevertheless, the origin and development of human senescent $\alpha \beta C D 8^{+} \mathrm{T}$ cells is distinct from that of classical innate $\mathrm{T}$ cells. While innate $\mathrm{T}$ cells are developmentally pre-programed in the thymus (12), $\alpha \beta C D 8^{+} \mathrm{T}$ cells with innate-like features arise in the periphery, most likely as a result of a general reprograming driven by external environmental cues. The different origin may explain why aging is associated with a decreased frequency of innate T cells such as NKT cells, as a result of thymic involution, whereas the number of conventional $\alpha \beta$ T cells expressing NKR increases in the elderly, most likely a result of the homeostatic redistribution of $\mathrm{T}$ cells to compensate for the decrease in the output of $\mathrm{T}$ cells from the thymus with age.

\section{PHYSIOLOGICAL ROLE OF INNATE-LIKE $\alpha \beta C D 8^{+}$T CELLS}

The capacity to mediate dual innate and adaptive immune functions place senescent $\alpha \beta C D 8^{+} \mathrm{T}$ cells alongside other innate-like cells in the frontline of defense against pathogens and tumors. The acquisition of innate sensors specialized in the recognition of "danger" signals allows these cells to switch to a rapid and efficient mode of action in potentially harmful situations. Given the increased burden of tumors and infections with age, the contribution of such innate-like CD8 ${ }^{+} \mathrm{T}$ cells may be crucial. The capacity to mediate MHC-unrestricted killing against a broad array of tumor targets has been demonstrated in vitro and in vivo with CIK cells putting these cells as attractive candidates for immunotherapy in solid organ and hematopoietic cancer treatment (102). Interestingly, despite showing a decreased TCR responsiveness, studies indicate that these cells still retain the capacity to elicit specific TCR-dependent immune responses (81).

\section{REFERENCES}

1. Lieberman J. Anatomy of a murder: how cytotoxic T cells and NK cells are activated, develop, and eliminate their targets. Immunol Rev (2010) 235(1):5-9. doi:10.1111/j.0105-2896.2010.00914.x

2. Medzhitov R, Janeway CA Jr. Innate immune recognition and control of adaptive immune responses. Semin Immunol (1998) 10(5):351-3. doi:10.1006/smim.1998.0136
Nevertheless, the reversal of antigen-specific $\mathrm{CD}^{+} \mathrm{T}$ cells to an innate mode of function is not without consequence. The peripheral requirement for TCR engagement for T cell activation is an important control mechanism to prevent autoreactivity. In conditions associated with chronic activation and inflammation, the balance between activating and inhibitory signals may favor the onset of autoimmune reactions. Recent reports have demonstrated a role of NKG2D in $\mathrm{CD}^{+} \mathrm{T}$ cell activation in inflammatory states and other stress conditions where NKG2D ligands are induced in normal tissues, such as celiac disease (6), type I diabetes (103), and transplantation $(104,105)$.

\section{CONCLUDING REMARKS}

In this review, we summarize evidence indicating that chronological aging is associated with accumulation of cells combining features of both the innate and adaptive arms of the immune system, most likely to compensate for functional defects of conventional $\mathrm{NK}$ and $\mathrm{CD} 8^{+} \mathrm{T}$ cells with age. We propose that senescent $\mathrm{CD}^{+} \mathrm{T}$ cells should not be seen as a dysfunctional population but instead a functionally distinct subset, which uses recently acquired NK cell machinery to maintain rapid effector functions throughout life. Contrary to the classic paradigm that peripheral TCR ligation is essential for T cell activation, this subset of highly differentiated $\mathrm{T}$ cells has impaired TCR responsiveness and may be non-specifically activated by inflammatory cytokines or after ligation of innate receptors. The switch to an innate mode of function may shed light on the mechanisms that allow highly differentiated $\mathrm{CD}^{+} \mathrm{T}$ cells to maintain they polyfunctionality, despite the loss of TCR signalosome.

Our understanding of the physiological significance of the expression of NKRs on T cells is still incomplete, and the identification of the molecular mechanisms and the transcriptional regulators underpinning the development of innate features in T cells is essential. Most importantly, it will be important to understand how the intersection between innate and adaptive immune features may be manipulated to enhance immune function and to use this information to develop new approaches to improve immunity in the elderly.

\section{AUTHOR CONTRIBUTIONS}

BP has done the literature search and writing. AA contributed for the writing and revising of the manuscript.

\section{FUNDING}

BP is funded by the Fundação Calouste Gulbenkian and Fundação Ciência e Tecnologia, Portugal.

3. O'Leary JG, Goodarzi M, Drayton DL, von Andrian UH. T cell- and B cell-independent adaptive immunity mediated by natural killer cells. Nat Immunol (2006) 7(5):507-16. doi:10.1038/ni1332

4. Sun JC, Beilke JN, Lanier LL. Adaptive immune features of natural killer cells. Nature (2009) 457(7229):557-61. doi:10.1038/nature07665

5. Berg RE, Crossley E, Murray S, Forman J. Memory CD8+ T cells provide innate immune protection against Listeria monocytogenes in the absence of cognate antigen. J Exp Med (2003) 198(10):1583-93. doi:10.1084/jem.20031051 
6. Meresse B, Chen Z, Ciszewski C, Tretiakova M, Bhagat G, Krausz TN, et al. Coordinated induction by IL15 of a TCR-independent NKG2D signaling pathway converts CTL into lymphokine-activated killer cells in celiac disease. Immunity (2004) 21(3):357-66. doi:10.1016/j.immuni.2004.06.020

7. Soudja SM, Ruiz AL, Marie JC, Lauvau G. Inflammatory monocytes activate memory CD8(+) T and innate NK lymphocytes independent of cognate antigen during microbial pathogen invasion. Immunity (2012) 37(3):549-62. doi:10.1016/j.immuni.2012.05.029

8. Bedoui S, Gebhardt T, Gasteiger G, Kastenmuller W. Parallels and differences between innate and adaptive lymphocytes. Nat Immunol (2016) 17(5):490-4. doi:10.1038/ni.3432

9. Kondo M, Weissman IL, Akashi K. Identification of clonogenic common lymphoid progenitors in mouse bone marrow. Cell (1997) 91(5):661-72. doi:10.1016/S0092-8674(00)80453-5

10. Strauss-Albee DM, Horowitz A, Parham P, Blish CA. Coordinated regulation of NK receptor expression in the maturing human immune system. J Immunol (2014) 193(10):4871-9. doi:10.4049/jimmunol.1401821

11. Best JA, Blair DA, Knell J, Yang E, Mayya V, Doedens A, et al. Transcriptional insights into the CD8(+) $\mathrm{T}$ cell response to infection and memory $\mathrm{T}$ cell formation. Nat Immunol (2013) 14(4):404-12. doi:10.1038/ni.2536

12. Vermijlen D, Prinz I. Ontogeny of innate T lymphocytes - some innate lymphocytes are more innate than others. Front Immunol (2014) 5:486. doi:10.3389/fimmu.2014.00486

13. Seyda M, Elkhal A, Quante M, Falk CS, Tullius SG. T cells going innate. Trends Immunol (2016) 37(8):546-56. doi:10.1016/j.it.2016.06.004

14. Paul WE. Bridging innate and adaptive immunity. Cell (2011) 147(6):1212-5. doi:10.1016/j.cell.2011.11.036

15. Dadi S, Chhangawala S, Whitlock BM, Franklin RA, Luo CT, Oh SA, et al. Cancer immunosurveillance by tissue-resident innate lymphoid cells and innate-like T cells. Cell (2016) 164(3):365-77. doi:10.1016/j.cell.2016. 01.002

16. Ettersperger J, Montcuquet N, Malamut G, Guegan N, Lopez-Lastra S, Gayraud S, et al. Interleukin-15-dependent T-cell-like innate intraepithelial lymphocytes develop in the intestine and transform into lymphomas in celiac disease. Immunity (2016) 45(3):610-25. doi:10.1016/j.immuni. 2016.07.018

17. Vallejo AN. Immune remodeling: lessons from repertoire alterations during chronological aging and in immune-mediated disease. Trends Mol Med (2007) 13(3):94-102. doi:10.1016/j.molmed.2007.01.005

18. Lynch HE, Goldberg GL, Chidgey A, Van den Brink MR, Boyd R, Sempowski GD. Thymic involution and immune reconstitution. Trends Immunol (2009) 30(7):366-73. doi:10.1016/j.it.2009.04.003

19. Linton PJ, Dorshkind K. Age-related changes in lymphocyte development and function. Nat Immunol (2004) 5(2):133-9. doi:10.1038/ni1033

20. Ouyang Q, Wagner WM, Voehringer D, Wikby A, Klatt T, Walter S, et al. Age-associated accumulation of CMV-specific CD8+ T cells expressing the inhibitory killer cell lectin-like receptor G1 (KLRG1). Exp Gerontol (2003) 38(8):911-20. doi:10.1016/S0531-5565(03)00134-7

21. Pawelec G, Gouttefangeas C. T-cell dysregulation caused by chronic antigenic stress: the role of CMV in immunosenescence? Aging Clin Exp Res (2006) 18(2):171-3. doi:10.1007/BF03327436

22. Akbar AN, Fletcher JM. Memory $\mathrm{T}$ cell homeostasis and senescence during aging. Curr Opin Immunol (2005) 17(5):480-5. doi:10.1016/j.coi. 2005.07.019

23. McElhaney JE, Zhou X, Talbot HK, Soethout E, Bleackley RC, Granville DJ, et al. The unmet need in the elderly: how immunosenescence, CMV infection, co-morbidities and frailty are a challenge for the development of more effective influenza vaccines. Vaccine (2012) 30(12):2060-7. doi:10.1016/j. vaccine.2012.01.015

24. Solana R, Tarazona R, Gayoso I, Lesur O, Dupuis G, Fulop T. Innate immunosenescence: effect of aging on cells and receptors of the innate immune system in humans. Semin Immunol (2012) 24(5):331-41. doi:10.1016/j. smim.2012.04.008

25. Le Garff-Tavernier M, Beziat V, Decocq J, Siguret V, Gandjbakhch F, Pautas E, et al. Human NK cells display major phenotypic and functional changes over the life span. Aging Cell (2010) 9(4):527-35. doi:10.1111/ j.1474-9726.2010.00584.x

26. Lopez-Verges S, Milush JM, Pandey S, York VA, Arakawa-Hoyt J, Pircher H, et al. CD57 defines a functionally distinct population of mature NK cells in the human CD56dimCD16+ NK-cell subset. Blood (2010) 116(19):3865-74. doi:10.1182/blood-2010-04-282301

27. Huntington ND, Tabarias H, Fairfax K, Brady J, Hayakawa Y, Degli-Esposti $\mathrm{MA}$, et al. NK cell maturation and peripheral homeostasis is associated with KLRG1 up-regulation. J Immunol (2007) 178(8):4764-70. doi:10.4049/ jimmunol.178.8.4764

28. Muller-Durovic B, Lanna A, Polaco Covre L, Mills RS, Henson SM, Akbar AN. Killer cell lectin-like receptor G1 inhibits NK cell function through activation of adenosine 5'-monophosphate-activated protein kinase. J Immunol (2016) 197(7):2891-9. doi:10.4049/jimmunol.1600590

29. Goronzy JJ, Weyand CM. Immune aging and autoimmunity. Cell Mol Life Sci (2012) 69(10):1615-23. doi:10.1007/s00018-012-0970-0

30. Sansoni P, Vescovini R, Fagnoni F, Biasini C, Zanni F, Zanlari L, et al. The immune system in extreme longevity. Exp Gerontol (2008) 43(2):61-5. doi:10.1016/j.exger.2007.06.008

31. Effros RB. Loss of CD28 expression on T lymphocytes: a marker of replicative senescence. Dev Comp Immunol (1997) 21(6):471-8. doi:10.1016/ S0145-305X(97)00027-X

32. Weng NP, Akbar AN, Goronzy J. CD28(-) T cells: their role in the age-associated decline of immune function. Trends Immunol (2009) 30(7):306-12. doi:10.1016/j.it.2009.03.013

33. Henson SM, Riddell NE, Akbar AN. Properties of end-stage human T cells defined by CD45RA re-expression. Curr Opin Immunol (2012) 24(4):476-81. doi:10.1016/j.coi.2012.04.001

34. Henson SM, Franzese O, Macaulay R, Libri V, Azevedo RI, Kiani-Alikhan S, et al. KLRG1 signaling induces defective Akt (ser473) phosphorylation and proliferative dysfunction of highly differentiated CD8+ T cells. Blood (2009) 113(26):6619-28. doi:10.1182/blood-2009-01-199588

35. Libri V, Azevedo RI, Jackson SE, Di Mitri D, Lachmann R, Fuhrmann S, et al. Cytomegalovirus infection induces the accumulation of short-lived, multifunctional CD4+CD45RA+CD27+ T cells: the potential involvement of interleukin-7 in this process. Immunology (2011) 132(3):326-39. doi:10.1111/j.1365-2567.2010.03386.x

36. Schirmer M, Goldberger C, Wurzner R, Duftner C, Pfeiffer KP, Clausen J, et al. Circulating cytotoxic CD8(+) CD28(-) T cells in ankylosing spondylitis. Arthritis Res (2002) 4(1):71-6. doi:10.1186/ar386

37. Di Mitri D, Azevedo RI, Henson SM, Libri V, Riddell NE, Macaulay R, et al. Reversible senescence in human CD4+CD45RA+CD27- memory T cells. J Immunol (2011) 187(5):2093-100. doi:10.4049/jimmunol.1100978

38. Henson SM, Lanna A, Riddell NE, Franzese O, Macaulay R, Griffiths SJ, et al. p38 signaling inhibits mTORC1-independent autophagy in senescent human CD8(+) T cells. J Clin Invest (2014) 124(9):4004-16. doi:10.1172/ JCI75051

39. Lanna A, Henson SM, Escors D, Akbar AN. The kinase p38 activated by the metabolic regulator AMPK and scaffold TAB 1 drives the senescence of human T cells. Nat Immunol (2014) 15(10):965-72. doi:10.1038/ni.2981

40. Lachmann R, Bajwa M, Vita S, Smith H, Cheek E, Akbar A, et al. Polyfunctional $\mathrm{T}$ cells accumulate in large human cytomegalovirus-specific $\mathrm{T}$ cell responses. J Virol (2012) 86(2):1001-9. doi:10.1128/JVI.00873-11

41. Akbar AN, Henson SM. Are senescence and exhaustion intertwined or unrelated processes that compromise immunity? Nat Rev Immunol (2011) 11(4):289-95. doi:10.1038/nri2959

42. Franceschi C, Bonafe M, Valensin S, Olivieri F, De Luca M, Ottaviani E, et al. Inflamm-aging. An evolutionary perspective on immunosenescence. Ann N Y Acad Sci (2000) 908:244-54. doi:10.1111/j.1749-6632.2000.tb06651.x

43. Larbi A, Pawelec G, Wong SC, Goldeck D, Tai JJ, Fulop T. Impact of age on T cell signaling: a general defect or specific alterations? Ageing Res Rev (2011) 10(3):370-8. doi:10.1016/j.arr.2010.09.008

44. Goronzy JJ, Li G, Yu M, Weyand CM. Signaling pathways in aged $\mathrm{T}$ cells - a reflection of $\mathrm{T}$ cell differentiation, cell senescence and host environment. Semin Immunol (2012) 24(5):365-72. doi:10.1016/j.smim.2012. 04.003

45. Fulop T Jr, Douziech N, Larbi A, Dupuis G. The role of lipid rafts in T lymphocyte signal transduction with aging. Ann N Y Acad Sci (2002) 973:302-4. doi:10.1111/j.1749-6632.2002.tb04655.x

46. Li G, Yu M, Lee WW, Tsang M, Krishnan E, Weyand CM, et al. Decline in miR-181a expression with age impairs $\mathrm{T}$ cell receptor sensitivity by increasing DUSP6 activity. Nat Med (2012) 18(10):1518-24. doi:10.1038/ $\mathrm{nm} .2963$ 
47. Mingueneau M, Roncagalli R, Gregoire C, Kissenpfennig A, Miazek A, Archambaud C, et al. Loss of the LAT adaptor converts antigen-responsive $\mathrm{T}$ cells into pathogenic effectors that function independently of the $\mathrm{T}$ cell receptor. Immunity (2009) 31(2):197-208. doi:10.1016/j.immuni. 2009.05.013

48. Broussard C, Fleischacker C, Horai R, Chetana M, Venegas AM, Sharp LL, et al. Altered development of CD8+ T cell lineages in mice deficient for the Tec kinases Itk and Rlk. Immunity (2006) 25(1):93-104. doi:10.1016/j. immuni.2006.05.011

49. Chu T, Tyznik AJ, Roepke S, Berkley AM, Woodward-Davis A, Pattacini L, et al. Bystander-activated memory CD8 T cells control early pathogen load in an innate-like, NKG2D-dependent manner. Cell Rep (2013) 3(3):701-8. doi:10.1016/j.celrep.2013.02.020

50. Tough DF, Borrow P, Sprent J. Induction of bystander T cell proliferation by viruses and type I interferon in vivo. Science (1996) 272(5270):1947-50. doi:10.1126/science.272.5270.1947

51. Kohlmeier JE, Cookenham T, Roberts AD, Miller SC, Woodland DL. Type I interferons regulate cytolytic activity of memory CD8(+) T cells in the lung airways during respiratory virus challenge. Immunity (2010) 33(1):96-105. doi:10.1016/j.immuni.2010.06.016

52. Liu K, Catalfamo M, Li Y, Henkart PA, Weng NP. IL-15 mimics T cell receptor crosslinking in the induction of cellular proliferation, gene expression, and cytotoxicity in CD8+ memory T cells. Proc Natl Acad Sci U S A (2002) 99(9):6192-7. doi:10.1073/pnas.092675799

53. Bou Ghanem EN, Nelson CC, D'Orazio SE. T cell-intrinsic factors contribute to the differential ability of CD8+ T cells to rapidly secrete IFN-gamma in the absence of antigen. J Immunol (2011) 186(3):1703-12. doi:10.4049/ jimmunol.1001960

54. Freeman BE, Hammarlund E, Raue HP, Slifka MK. Regulation of innate CD8+ T-cell activation mediated by cytokines. Proc Natl Acad Sci U S A (2012) 109(25):9971-6. doi:10.1073/pnas.1203543109

55. Meresse B, Curran SA, Ciszewski C, Orbelyan G, Setty M, Bhagat G, et al. Reprogramming of CTLs into natural killer-like cells in celiac disease. J Exp Med (2006) 203(5):1343-55. doi:10.1084/jem.20060028

56. Bauer S, Groh V, Wu J, Steinle A, Phillips JH, Lanier LL, et al. Activation of NK cells and T cells by NKG2D, a receptor for stress-inducible MICA. Science (1999) 285(5428):727-9. doi:10.1126/science.285.5428.727

57. Raulet DH. Roles of the NKG2D immunoreceptor and its ligands. Nat Rev Immunol (2003) 3(10):781-90. doi:10.1038/nri1199

58. Groh V, Rhinehart R, Randolph-Habecker J, Topp MS, Riddell SR, Spies T. Costimulation of CD8alphabeta T cells by NKG2D via engagement by MIC induced on virus-infected cells. Nat Immunol (2001) 2(3):255-60. doi: $10.1038 / 85321$

59. Diefenbach A, Jensen ER, Jamieson AM, Raulet DH. Rae1 and H60 ligands of the NKG2D receptor stimulate tumour immunity. Nature (2001) 413(6852):165-71. doi:10.1038/35093109

60. Groh V, Wu J, Yee C, Spies T. Tumour-derived soluble MIC ligands impair expression of NKG2D and T-cell activation. Nature (2002) 419(6908):734-8. doi:10.1038/nature01112

61. Verneris MR, Karami M, Baker J, Jayaswal A, Negrin RS. Role of NKG2D signaling in the cytotoxicity of activated and expanded CD8+ T cells. Blood (2004) 103(8):3065-72. doi:10.1182/blood-2003-06-2125

62. Lemster BH, Michel JJ, Montag DT, Paat JJ, Studenski SA, Newman AB, et al. Induction of CD56 and TCR-independent activation of T cells with aging. J Immunol (2008) 180(3):1979-90. doi:10.4049/jimmunol.180. 3.1979

63. Wang H, Yang D, Xu W, Wang Y, Ruan Z, Zhao T, et al. Tumor-derived soluble MICs impair CD3(+)CD56(+) NKT-like cell cytotoxicity in cancer patients. Immunol Lett (2008) 120(1-2):65-71. doi:10.1016/j.imlet. 2008.07.001

64. Miyaji C, Watanabe H, Minagawa M, Toma H, Kawamura T, Nohara Y, et al. Numerical and functional characteristics of lymphocyte subsets in centenarians. JClin Immunol (1997) 17(5):420-9. doi:10.1023/ A:1027324626199

65. Pittet MJ, Speiser DE, Valmori D, Cerottini JC, Romero P. Cutting edge: cytolytic effector function in human circulating CD8+ T cells closely correlates with CD56 surface expression. J Immunol (2000) 164(3):1148-52. doi:10.4049/jimmunol.164.3.1148
66. Tarazona R, DelaRosa O, Alonso C, Ostos B, Espejo J, Pena J, et al. Increased expression of $\mathrm{NK}$ cell markers on $\mathrm{T}$ lymphocytes in aging and chronic activation of the immune system reflects the accumulation of effector/ senescent T cells. Mech Ageing Dev (2000) 121(1-3):77-88. doi:10.1016/ S0047-6374(00)00199-8

67. Abedin S, Michel JJ, Lemster B, Vallejo AN. Diversity of NKR expression in aging $\mathrm{T}$ cells and in $\mathrm{T}$ cells of the aged: the new frontier into the exploration of protective immunity in the elderly. Exp Gerontol (2005) 40(7):537-48. doi:10.1016/j.exger.2005.04.012

68. Vallejo AN, Mueller RG, Hamel DL Jr, Way A, Dvergsten JA, Griffin P, et al. Expansions of NK-like alphabetaT cells with chronologic aging: novel lymphocyte effectors that compensate for functional deficits of conventional NK cells and T cells. Ageing Res Rev (2011) 10(3):354-61. doi:10.1016/j. arr.2010.09.006

69. Brenchley JM, Karandikar NJ, Betts MR, Ambrozak DR, Hill BJ, Crotty LE, et al. Expression of CD57 defines replicative senescence and antigen-induced apoptotic death of CD8+ T cells. Blood (2003) 101(7):2711-20. doi:10.1182/ blood-2002-07-2103

70. Casado JG, Soto R, DelaRosa O, Peralbo E, del Carmen MunozVillanueva M, Rioja L, et al. CD8 T cells expressing NK associated receptors are increased in melanoma patients and display an effector phenotype. Cancer Immunol Immunother (2005) 54(12):1162-71. doi:10.1007/ s00262-005-0682-5

71. Franceschetti M, Pievani A, Borleri G, Vago L, Fleischhauer K, Golay J, et al. Cytokine-induced killer cells are terminally differentiated activated CD8 cytotoxic T-EMRA lymphocytes. Exp Hematol (2009) 37(5):616-28.e2 doi:10.1016/j.exphem.2009.01.010

72. Alonso-Arias R, Moro-Garcia MA, Lopez-Vazquez A, Rodrigo L, Baltar J, Garcia FM, et al. NKG2D expression in CD4+ T lymphocytes as a marker of senescence in the aged immune system. Age (2011) 33(4):591-605. doi:10.1007/s11357-010-9200-6

73. Groh V, Bruhl A, El-Gabalawy H, Nelson JL, Spies T. Stimulation of T cell autoreactivity by anomalous expression of NKG2D and its MIC ligands in rheumatoid arthritis. Proc Natl Acad Sci U S A (2003) 100(16):9452-7. doi:10.1073/pnas.1632807100

74. Phoksawat W, Jumnainsong A, Leelayuwat N, Leelayuwat C. Aberrant NKG2D expression with IL-17 production of CD4+ T subsets in patients with type 2 diabetes. Immunobiology (2016). doi:10.1016/j.imbio.2016. 05.001

75. Verneris MR, Karimi M, Baker J, Jayaswal A, Negrin RS. Role of NKG2D signaling in the cytotoxicity of activated and expanded CD8+ T cells. Blood (2004) 103(8):3065-72. doi:10.1182/blood-2003-06-2125

76. Roberts AI, Lee L, Schwarz E, Groh V, Spies T, Ebert EC, et al. NKG2D receptors induced by IL-15 costimulate CD28-negative effector CTL in the tissue microenvironment. J Immunol (2001) 167(10):5527-30. doi:10.4049/ jimmunol.167.10.5527

77. van Stijn A, Rowshani AT, Yong SL, Baas F, Roosnek E, ten Berge IJ, et al. Human cytomegalovirus infection induces a rapid and sustained change in the expression of NK cell receptors on CD8+ T cells. J Immunol (2008) 180(7):4550-60. doi:10.4049/jimmunol.180.7.4550

78. Ugolini S, Arpin C, Anfossi N, Walzer T, Cambiaggi A, Forster R, et al. Involvement of inhibitory NKRs in the survival of a subset of memoryphenotype CD8+ T cells. Nat Immunol (2001) 2(5):430-5. doi:10.1038/ 85246

79. Vivier E, Anfossi N. Inhibitory NK-cell receptors on T cells: witness of the past, actors of the future. Nat Rev Immunol (2004) 4(3):190-8. doi:10.1038/ nri1306

80. Zhang Q, Liu XY, Zhang T, Zhang XF, Zhao L, Long F, et al. The dual-functional capability of cytokine-induced killer cells and application in tumor immunology. Hum Immunol (2015) 76(5):385-91. doi:10.1016/j. humimm.2014.09.021

81. Pievani A, Borleri G, Pende D, Moretta L, Rambaldi A, Golay J, et al. Dualfunctional capability of CD3+CD56+ CIK cells, a T-cell subset that acquires NK function and retains TCR-mediated specific cytotoxicity. Blood (2011) 118(12):3301-10. doi:10.1182/blood-2011-02-336321

82. Chen G, Lustig A, Weng NP. T cell aging: a review of the transcriptional changes determined from genome-wide analysis. Front Immunol (2013) 4:121. doi:10.3389/fimmu.2013.00121 
83. Fann M, Chiu WK, Wood WH III, Levine BL, Becker KG, Weng NP. Gene expression characteristics of CD28null memory phenotype CD8+ T cells and its implication in T-cell aging. Immunol Rev (2005) 205:190-206. doi:10.1111/j.0105-2896.2005.00262.x

84. Lazuardi L, Herndler-Brandstetter D, Brunner S, Laschober GT, Lepperdinger G, Grubeck-Loebenstein B. Microarray analysis reveals similarity between CD8+CD28- T cells from young and elderly persons, but not of CD8+CD28+ T cells. Biogerontology (2009) 10(2):191-202. doi:10.1007/ s10522-008-9167-1

85. Cao JN, Gollapudi S, Sharman EH, Jia Z, Gupta S. Age-related alterations of gene expression patterns in human CD8+ T cells. Aging Cell (2010) 9(1):19-31. doi:10.1111/j.1474-9726.2010.00569.x

86. Hedrick SM, Hess Michelini R, Doedens AL, Goldrath AW, Stone EL. FOXO transcription factors throughout T cell biology. Nat Rev Immunol (2012) 12(9):649-61. doi:10.1038/nri3278

87. Rutishauser RL, Martins GA, Kalachikov S, Chandele A, Parish IA, Meffre E, et al. Transcriptional repressor Blimp-1 promotes CD8(+) T cell terminal differentiation and represses the acquisition of central memory T cell properties. Immunity (2009) 31(2):296-308. doi:10.1016/j.immuni. 2009.05.014

88. Kallies A, Xin A, Belz GT, Nutt SL. Blimp-1 transcription factor is required for the differentiation of effector CD8(+) T cells and memory responses. Immunity (2009) 31(2):283-95. doi:10.1016/j.immuni.2009. 06.021

89. Dominguez CX, Amezquita RA, Guan T, Marshall HD, Joshi NS, Kleinstein SH, et al. The transcription factors ZEB2 and T-bet cooperate to program cytotoxic $\mathrm{T}$ cell terminal differentiation in response to LCMV viral infection. J Exp Med (2015) 212(12):2041-56. doi:10.1084/jem. 20150186

90. Kovalovsky D, Alonzo ES, Uche OU, Eidson M, Nichols KE, Sant’Angelo DB. PLZF induces the spontaneous acquisition of memory/effector functions in T cells independently of NKT cell-related signals. J Immunol (2010) 184(12):6746-55. doi:10.4049/jimmunol.1000776

91. Townsend MJ, Weinmann AS, Matsuda JL, Salomon R, Farnham PJ, Biron $\mathrm{CA}$, et al. T-bet regulates the terminal maturation and homeostasis of NK and Valpha14i NKT cells. Immunity (2004) 20(4):477-94. doi:10.1016/ S1074-7613(04)00076-7

92. Kovalovsky D, Uche OU, Eladad S, Hobbs RM, Yi W, Alonzo E, et al. The BTB-zinc finger transcriptional regulator PLZF controls the development of invariant natural killer T cell effector functions. Nat Immunol (2008) 9(9):1055-64. doi:10.1038/ni.1641

93. Alonzo ES, Sant'Angelo DB. Development of PLZF-expressing innate T cells. Curr Opin Immunol (2011) 23(2):220-7. doi:10.1016/j.coi.2010.12.016

94. Brennan PJ, Brigl M, Brenner MB. Invariant natural killer T cells: an innate activation scheme linked to diverse effector functions. Nat Rev Immunol (2013) 13(2):101-17. doi:10.1038/nri3369

95. Jing Y, Gravenstein S, Chaganty NR, Chen N, Lyerly KH, Joyce S, et al. Aging is associated with a rapid decline in frequency, alterations in subset composition, and enhanced Th2 response in CD1d-restricted NKT cells from human peripheral blood. Exp Gerontol (2007) 42(8):719-32. doi:10.1016/j. exger.2007.01.009
96. Peralbo E, DelaRosa O, Gayoso I, Pita ML, Tarazona R, Solana R. Decreased frequency and proliferative response of invariant Valpha24Vbeta11 natural killer T (iNKT) cells in healthy elderly. Biogerontology (2006) 7(5-6):483-92. doi:10.1007/s10522-006-9063-5

97. Wencker M, Turchinovich G, Di Marco Barros R, Deban L, Jandke A, Cope A, et al. Innate-like $\mathrm{T}$ cells straddle innate and adaptive immunity by altering antigen-receptor responsiveness. Nat Immunol (2014) 15(1):80-7. doi:10.1038/ni.2773

98. Wang X, Bishop KA, Hegde S, Rodenkirch LA, Pike JW, Gumperz JE. Human invariant natural killer $\mathrm{T}$ cells acquire transient innate responsiveness via histone H4 acetylation induced by weak TCR stimulation. J Exp Med (2012) 209(5):987-1000. doi:10.1084/jem.20111024

99. Nitahara A, Shimura H, Ito A, Tomiyama K, Ito M, Kawai K. NKG2D ligation without $\mathrm{T}$ cell receptor engagement triggers both cytotoxicity and cytokine production in dendritic epidermal T cells. J Invest Dermatol (2006) 126(5):1052-8. doi:10.1038/sj.jid.5700112

100. Shafi S, Vantourout P, Wallace G, Antoun A, Vaughan R, Stanford M, et al. An NKG2D-mediated human lymphoid stress surveillance response with high interindividual variation. Sci Transl Med (2011) 3(113):113ra24. doi:10.1126/ scitranslmed.3002922

101. Strid J, Roberts SJ, Filler RB, Lewis JM, Kwong BY, Schpero W, et al. Acute upregulation of an NKG2D ligand promotes rapid reorganization of a local immune compartment with pleiotropic effects on carcinogenesis. Nat Immunol (2008) 9(2):146-54. doi:10.1038/ni1556

102. Hontscha C, Borck Y, Zhou H, Messmer D, Schmidt-Wolf IG. Clinical trials on CIK cells: first report of the international registry on CIK cells (IRCC). J Cancer Res Clin Oncol (2011) 137(2):305-10. doi:10.1007/ s00432-010-0887-7

103. Ogasawara K, Hamerman JA, Ehrlich LR, Bour-Jordan H, Santamaria $\mathrm{P}$, Bluestone JA, et al. NKG2D blockade prevents autoimmune diabetes in NOD mice. Immunity (2004) 20(6):757-67. doi:10.1016/j. immuni.2004.05.008

104. Li J, Zhu H, Wang S, Ye P, Liu C, Wu J, et al. Blockade of NKG2D synergized with CTLA4-Ig in promoting long-term graft survival in murine models of cardiac transplantation. Transplantation (2012) 93(4):356-63. doi:10.1097/ TP.0b013e31823ffce7

105. Karimi MA, Bryson JL, Richman LP, Fesnak AD, Leichner TM, Satake A, et al. NKG2D expression by CD8+ T cells contributes to GVHD and GVT effects in a murine model of allogeneic HSCT. Blood (2015) 125(23):3655-63. doi:10.1182/blood-2015-02-629006

Conflict of Interest Statement: The authors declare that the research was conducted in the absence of any commercial or financial relationships that could be construed as a potential conflict of interest.

Copyright (c) 2016 Pereira and Akbar. This is an open-access article distributed under the terms of the Creative Commons Attribution License (CC BY). The use, distribution or reproduction in other forums is permitted, provided the original author(s) or licensor are credited and that the original publication in this journal is cited, in accordance with accepted academic practice. No use, distribution or reproduction is permitted which does not comply with these terms. 